\title{
지카바이러스 감염
}

${ }^{1}$ 서울특별시 서북병원 감염내과, ${ }^{2}$ 성균관대학교 의과대학 강북삼성병원 감염내과

윤희정 ${ }^{1} \cdot$ 염준섭 $^{2}$

\section{Zika Virus Infection}

\author{
Hee Jung Yoon and Joon-Sup Yeom \\ ${ }^{1}$ Division of Infectious Diseases, Seoul Metropolitan Government Seobuk Hospital, Seoul; \\ ${ }^{2}$ Division of Infectious Diseases, Kangbuk Samsung Hospital, Sungkyunkwan University School of Medicine, Seoul, Korea
}

Zika virus was first isolated in from nonhuman primate in 1947. It is in the genus Flavivirus, closely related to other flavivirus like Dengue, West Nile, Yellow fever and Japanese encephalitis virus. Since 2007 epidemic in Yap island, zika virus infections had spread to the countries in Micronesia and South Pacific. In 2015, Zika virus outbreak occurred in Brazil and now more than 40 countries in American continents reported autochthonous infection. The virus is transmitted mainly by Ae. aegypti mosquito with many other Aedes mosquito species known as vector. Recently, Zika virus infection is known to cause severe neurological complications and congenital malformation. In this paper, we will review current knowledge on Zika virus history, biology, clinical characteristics and preventive method. (Korean J Med 2016;91:5-11)

Keywords: Zika virus; Flavivirus; Microcephaly; Aedes

\section{서 론}

지카바이러스는 Flavivirus 속(genus), Flaviviridae 과(family) 에 속하는 외가닥 양방향 비분절 RNA바이러스(ss-nonsegmented RNA of positive sense)이다[1]. 루간다어로 '울창 한'이란 뜻을 가진 'zika'는 바이러스가 최초 발견된 우간다 의 숲 이름이기도 하다[2]. 1947년 바이러스가 처음 발견된 이후 아프리카, 동남아시아 일부 국가에서 산발적 발생 보고 가 있었으나 큰 관심의 대상이 되지 못했고, 2007년 Yap island에서 큰 유행이 발생한 이후 태평양의 여러 섬나라로 질
병이 확산되었다. 2015년부터 브라질을 중심으로 아메리카 대륙에서 큰 유행이 시작되었고 현재까지 중앙 및 남아메리 카의 41개 국가에서 유행이 지속되고 있다[3] (Table 1). 지카 바이러스 감염이 소두증, 길렝-바레증후군(Guillain-Barré syndrome, GBS) 등 신경계 질환을 유발할 수 있는 것으로 알려지 고 점차 여러 국가로 확산되면서 2016년 2월 1일 세계보건기 구(World Health Organization, WHO)는 국제 공중보건 비상 사태를 선언하게 되었고, 이어 미국 Centers for Diseases Control and Prevention도 2016년 2월 8일 1단계로 위기 반응 단계를 상향시켰다. 국내에서는 해외 일부 국가에서 유행하

Correspondence to Joon-Sup Yeom, M.D., Ph.D.

Division of Infectious Diseases, Kangbuk Samsung Hospital, Sungkyunkwan University School of Medicine, 29 Saemunan-ro, Jongno-gu, Seoul 03181, Korea

Tel: +82-2-2001-2474, Fax: +82-2-2001-1596, E-mail: jsyeom@skku.edu 
- The Korean Journal of Medicine: Vol. 91, No. 1, 2016 -

고 있는 지카바이러스 감염증의 선제적 대응을 위해 2016년 1월 29일 제4군 법정 감염병으로 지정되었다.

\section{역 학}

1947년 우간다 지카숲에서 황열(yellow fever)의 전염 기전 을 연구하던 중 Rhesus 원숭이로부터 처음 바이러스가 분리 되었다. 이어 1948년 지카숲의 Aedes africanus 모기에서도 분리되었고[4,5], 1954년 아프리카에서 최초로 인간 감염자 가 확인되었다[6]. 아프리카 외 지역으로는 1966년 말레이시 아 Ae. aegypti 모기에서 바이러스가 처음 분리되었다. 1977 년에는 인도네시아 자바섬에서 7명의 사례가 보고되었고[7], 2007년에는 가봉 Libreville에서 뎅기열과 치쿤구니야병의 발 생이 보고되었는데 이 중 5 명의 사람 검체와 2 개의 Ae. albopictus 모기에서 이 바이러스가 발견되었다. 산발적 발생으로 학계의 주목을 받지 못하던 지카바이러스 감염증은 2007년 Yap Island의 유행이 학계에 보고되면서 주목받게 되었다[8]. 인구 6,700 명의 서태평양 미크로네시아 연방에 위치한 작은 섬인 Yap island에서 시행된 연구에 따르면, 발진, 결막염, 열, 관절통을 호소하는 108 명의 발생 사례 중 49 명이 지카바이 러스에 대한 reverse transcriptase-polymerase chain reaction (RT-PCR) 검사에서 양성이었고, 7,391명의 거주자 중 $73 \%$ 가 지카바이러스 항체 양성 반응을 보였으며, 매개 모기는 $A e$. hensilli로 추정되었다[8,9]. 이후 캄보디아, 필리핀, 태국에서 국소적인 발생이 보고되었고, 2013년 French Polynesia에서 전 인구의 $10 \%$ 에 해당하는 19,000 여 명에서 뎅기열과 유사 한 증상을 보이는 큰 유행이 발생하여, 294/584명에서 지카 바이러스 RT-PCR 양성으로 확진되었다[4,10]. 72명의 감염
자에서 신경학적 혹은 자가면역 합병증이 나타났지만 사망 자는 없었다. 이후 지카바이러스 유행은 New Caledonia, Cook Island, Vanuatu, Solomon Island 등의 남태평양 섬들로 확산되었다[4,11]. French Polynesia에서 발생한 유행을 통해 혈액 전파가 가능하고, 정액, 타액, 소변에서도 바이러스가 검출되는 것을 발견하였다. 2014년에는 태국 여행에서 돌아 온 독일 여행자에게서 유럽 첫 유입 사례가 보고되었고, 이 어서 캐나다, 미국, 호주, 일본, 노르웨이, 이탈리아 등 여러 국가에서도 유입 사례가 보고되었다. 2014년 1월에서 5월까 지 이스터섬의 French Polynesia에서 기원한 지카바이러스에 의한 51예의 토착 감염 사례가 보고되었고, 2015년부터 브라 질 북동부에서 유행이 시작되어, 2016년 7월까지 브라질에 서만 166,000 여 명의 추정 감염자와 66,180 명의 확진자, 8,039 예의 소두증 의심 사례와 1,616 예의 선천성 감염에 의한 소 두증이 보고되었다[12-14]. 국내에서는 2016년 3월 브라질을 다녀온 43세 남자에서 첫 감염이 보고되었고[15], 2016년 7 월까지 총 9예의 해외 유입 사례가 있었다.

\section{바이러스의 분류}

계통학적으로 African lineage와 Asian lineage로 분류된다 [16]. African lineage에는 East African (prototype Uganda strain)과 West African (Senegal strain)이 있고Asian lineage에 는 Malaysia, Yap, 캄보디아 strain이 있다[17]. 지카바이러스 의 구조는 3 개의 구조적 단백질(capsid, precursor membrane, envelope), 7개의 비구조적 단백질(NS1, NS2a, NS2b, NS3, $\mathrm{NS} 4 \mathrm{a}, \mathrm{NS} 4 \mathrm{~b}, \mathrm{NS} 5$ )로 이루어져 있다[4,11]. 지카바이러스 envelope protein은 수용체 부착과 융합에 중요한 단백질인데

\section{Table 1. Countries with Zika virus transmission [3]}

\begin{tabular}{lcc}
\hline Location & \multicolumn{1}{c}{ Countries with Zika virus transmission since 2015 } & $\begin{array}{c}\text { Countries with Zika virus transmission re- } \\
\text { ported before 2015 }\end{array}$ \\
\hline Asia & Vietnam, Philippines, Thailand, Indonesia, Moldives & Laos, Malaysia, Bangladash, Cambodia \\
& Guiana, Guadeloupe, Guatemala, Grenades, Nicaragua, Bonaire & \\
& Island, St. Martin, Aruba, Curacao, Dominican Republic, & \\
Dominica, Martinique, Mexico, Virgin island, Barbeidos, & \\
Central and & Venezuela, Beliz, Bolivia, Brazil, Surinam, St. Vincent and & Chile (Easter island) \\
South America & Grenadines, St. Lucia, Argentina, Haiti, Equador, El Salvador, & \\
& Honduras, Jamaica, Costa Ricca, Colombia, Cuba, Trinidad & \\
& Tobago, Pananma, Paraguay, Puerto Ricco, French Guyana, St. & \\
Martin, St. Barthelemy, Peru & \\
Oceania & Marshall Island, Tonga, American Samoa, Samoa, Fiji, New & Cook Island, French Polynesia, Solomon \\
Africa & Caledonia, Federal State of Microniesia, Papua New Guinea & Islands, Vanuatu \\
\hline
\end{tabular}


신경계에 악영향을 미치는 다른 웨스트나일바이러스, 일본 뇌염바이러스 등의 flavivirus 단백과 유사하다[18]. 이 단백 질에 있는 N-linked glycosylation site의 반복적인 손실과 이득 을 통해 유전적 적응된 진화 과정을 거쳤으며 이는 모기 세 포 감염력과 연관이 있다.

\section{전 파}

주요 전파 경로는 감염된 모기를 통한 모기와 사람간의 전파이며 혈액과 정액 등을 통한 사람간 전파도 가능하다. 암컷 모기가 흡혈시 바이러스가 전파되며 수컷 모기의 경우 수직 전파로 감염이 가능하다. 매개 모기는 지역에 따라 다 르며 Ae. africanus, Ae. furcifer, Ae. luteocephalus, Ae. vittatus, Ae. dalzieli, Ae. hirsutus, Ae. metalicus, Ae. taylori, Ae. aegypti, Ae. unilineatus, An. coustani, Culex perfuscus, Mansonia uniformis 등이 알려져 있다[4,11]. 큰 유행이 있었던 Yap island 에서는 비록 바이러스가 동정되지는 않았으나Ae. Hensilii가 매개 모기로 추정되었고 광범위한 지역에 분포하여 지카바 이러스 확산에 가장 큰 위협으로 지목된 Ae. albopictus는 Gabon외에는 아직까지 타 지역에서 유행을 매개하지 않았다 [4]. 브라질로 지카바이러스가 전파된 경로에 대해서는 3 가 지 가설이 있는데, 첫 번째는 2013년 7월 프란체스코 교황이 세계 청소년의 날을 기념하여 리오데자네이로에 방문시 그 를 보려고 아프리카와 아시아 국가에서 온 방문객들을 통해 서이거나, 두 번째 가설은 2014년 6-7월 월드컵 당시 브라질 여러 주(Natal Recife, Salvador, Fortaleza)에서 경기가 개최되 었을 때 유입되었을 가능성, 세 번째로 2014년 8월 리오에서 개최된 카누 경기 대회에는 태평양 섬(French Polynesia, New Caledonia, Cook Island, Easter Island)에서 경기자들의 참여가 많았는데 이 때 유입되었을 가능성이 제기되어지고 있다. 최 근 바이러스의 계통학적 연구에 근거할 때 바이러스는 French Polynesia에서 발견된 Asian lineage이며 2013년 5월에 서 12월 사이에 유입된 것으로 추정된다[19].

성관계를 통한 감염은 현재 10 개국에서 보고되어 있다. 지 카바이러스는 소변, 타액, 양수, 정액에서 발견되었고, 특히 정액에서는 증상 발현 후 62일까지도 발견되었다[20]. 2008 년 세네갈 다녀온 두 명의 과학자 중 한 명이 부인과 성관계 후 전염된 사례가 있었고[21], 2016년 1월 베네주엘라에서 지카바이러스에 감염된 남성이 남성파트너에게 감염시킨 사 례가 있었다[22]. 캐나다, 아르헨티나, 칠레, 프랑스, 이탈리
아에서도 성관계를 통함 감염 사례가 보고되었다[23]. 이 밖 에 수혈, 수유로 인한 감염도 가능하다[4,11].

\section{병 인}

모기에 물린 후 3-11일 후 증상이 시작되며, 바이러스혈증 은 0-11일 정도이나 대부분 6일 미만이다. 바이러스는 진피 섬유세포, 표피 각질세포, 미성숙 수지돌기상 세포를 포함한 피부세포에 침투하여 지카바이러스 감염을 유발하고, 감염 된 섬유세포에서는 interferon (IFN)- $\alpha, \beta$ 유전자가 활성화되어 $\mathrm{OAS} 2, \mathrm{ISG} 15, \mathrm{MX} 1$ 과 같은 IFN 자극 유전자가 활성화되는 항바이러스 상태를 유도하여 type I과 type III 인터페론이 지 카바이러스 복제를 방해한다. 지카바이러스는 TLR-3, RIG-1, MDA-5 유전자를 활성화시키고, autophagosome과 autophagy 는 피부 섬유 세포에서 바이러스 활성화와 연관되어 있었다 [11]. 지카바이러스가 신경세포친화적이라는 기전 외에 감염 이 되면 molecular mimicry, epitope spreading, bystander activation, super-antigen 생산, 면역 반응의 과도활성 등의 기전을 통하여 자가면역 질환을 유발할 수 있다. Ganglioside는 신경 계에 있는 sialic acid 포함 glycolipid로 이에 대한 항체가 GBS 병인에 중요한 역할을 한다. 체내 세포와 조직에 있는 glycolipid와 감염 바이러스에 있는 표면 분자 사이 molecular mimicry를 통해 GBS가 발병할 수 있다. 자가항체 항원의 특이성 에 따라 $\mathrm{GBS}$ 의 다양한 임상적 아형이 정해진다. 또 자가항체 특이성은 binding site drift 가설로 설명할 수 있는데 이 가설 은 B세포가 생산한 정상적인 항 ganglioside 항체가 V유전자 변이를 거쳐 부착 부위의 ganglioside의 부착 부위와 특이성 을 증가시켜 염증 반응을 일으키게 된다는 것이다. Ganglioside 중 GM1, GD1a, GD1b, GT1은 뇌에 많고, 특히 회색질에 는 백색질보다 5배 이상 많아 이들이 neurogenesis, synaptogenesis, synaptic transmission, 세포활성에 역할을 하는 뇌 발 달에 중요한 영향을 미친다. 즉, 바이러스가 체내 세포막에 glycolipid/glycoprotein이 발달할 때 끼어들어가 항원이 되고, 이는 major histocompatibility complex와 결합하여 면역 반응 을 일으키게 되고 다른 신경세포에 의해 표출되는 비슷한 구 조와 교차 반응하게 된다[24].

\section{증 상}

감염자의 $80 \%$ 는 증상이 없다. 무증상에서부터 발진, 열, 
관절통, 두통, 결막염, 오한, 피로, 사지부종, 후안통, 현기증, 근육통, 소화기계 병증, 경부임파선증, 혈뇨, 혈정자증 등이 수일 지속되다가 회복된다. 심한 경우에는 GBS, 뇌수막염, 급성 미만성 뇌염과 같은 신경학적 합병증, 혈소판감소자반 증, 백혈구감소증과 같은 자가면역합병증, 소두증, 태아 기 형과 같은 증상이 생기기도 한다[4,11].

\section{소두증}

2015년 9월부터 지카바이러스 유행 지역에서 지카바이러 스 감염과 태아의 소두증과의 연관성이 꾸준히 제기되어 왔 다. 브라질 정부에서는 2015년 10월에서 2016년 4월 9일 사이 27 개 주 중 21 개 주에서 7,015 소두증 증례를 보고하였고, 1,113 예가 지카바이러스에 의한 소두증이 확인되었다고 하 였으며 이 중 235예가 사망하였다[25]. 이 수치는 과거 5년간 의 평균 수치의 20 배에 달하는 수치이다. 소두증의 정의는 정립된 기준은 없지만, 일반적으로 전두-후두 머리둘레로 출 생 24시간에 머리 둘레가 평균 $1 / 3$ percentile 이하에 속하는 수치로 정의하고, 유전적, 감염성(TORCH; toxoplasmosis, others [syphilis, varicella-zoster, parvovirus B19], rubella, cytomegalovirus, herpes infections), 환경적 원인이 배제되어야 한다 [11]. 브라질 북동부 지역에서 지카바이러스에 감염된 후 슬 로베니아로 귀국한 산모의 유산한 태아를 부검한 결과 소두 증, 무대뇌피질증, 수두증을 보였고, 태아의 뇌조직에서 지카 바이러스가 검출되었다[26]. 지카바이러스에 감염된 23명의 영아에서 컴퓨터단층촬영 소견을 관찰한 결과 대뇌피질의 석회화, 무대뇌피질, 뇌실확장, 소뇌부전증 등의 소견이 관찰 되었다[27,28]. 최근 브라질 연구팀에 의하면 신경 만능줄기 세포 5 개 중 하나가 지카바이러스에 감염되었으며 감염 3 일 뒤부터 기형이 되었고, 6 일이 지나자 만들어진 수백 개의 neurospheres 중 극히 일부만 생존했으며, 지카바이러스에 감 염된 신경 줄기세포로 만든 뇌 유사조직의 크기가 정상에 비 해 $40 \%$ 작다고 밝혔다[29]. 또한 지카바이러스에 감염된 임 산부가 소두증 신생아를 출산할 확률은 $1-29 \%$ 에 달하며, 3 개 월 이내 임신 초기의 임산부가 지카바이러스에 감염됐을 때 소두증 신생아를 출산할 확률이 보통 임산부에 비해 50 배 이 상 높았다는 연구 결과들이 발표되었다[29,30].

\section{길렝-바레 증후군(GBS)}

GBS는 감염 2-8주 후에 유발되는 자가면역성 다발 수지 성 신경병증으로, 하지로부터 시작되는 운동실조, 심부 건반
사의 소실, 뇌신경 장애를 특징으로 한다. 2013년 French Polynesia에서 지카바이러스 감염자에서 GBS가 의미 있게 많았으며[31], 2015년 7월 브라질 바히아 주에서 42예의 GBS 환자를 보고하였고, 25 예에서 지카바이러스 감염에 합당한 증상을 가지고 있었다. 2015년 한 해에만 1,708 명의 GBS 환 자가 보고되었고, 이는 2014년에 비해 $19 \%$ 증가한 소견이다. 콜럼비아, 엘살바도르, 수리남, 베네주엘라에서도 GBS 환자 가 증가함을 보고하였다[25].

\section{기타}

이 밖에 뇌 합병증으로 급성 산재성 뇌척수염(acute diffuse encephalomyelitis, $\mathrm{ADEM}$ ), 급성 척수염 등이 보고되었다. $\mathrm{ADEM}$ 은 다발성 경화증과 증세가 비슷하나 급성이고 고열, 위약, 시력 손상, 혼수 등을 초래할 수 있다. 이는 뇌신경, 척 수신경, 또는 시신경을 싸고 있는 myelin에 염증을 초래하여 손상시키기 때문이다. 브라질 Pernambuco주 Recife시에 있는 병원에서 지카바이러스에 감염된 180 명을 조사한 결과 이 중 30 명이 $\mathrm{ADEM}$ 이 있었고, 60 명은 $\mathrm{GBS}$ 를 가지고 있었다[26].

\section{진 단}

임상적, 역학적 특성과 함께 검사법의 특성을 고려하여 진 단한다[32]. 2개월 내에 지카바이러스 감염증 발생 국가 여 행력이 있으면서 2주 내에 발진과 함께 관절통, 근육통, 결막 염, 두통 중 하나가 동반될 때 의심 환자로 분류하고 검사를 시행한다[33]. 진단 방법으로는 크게 분자학적 진단과 혈청 학적 진단으로 나눌 수 있는데, 분자학적 진단법에 RT-PCR 이 있다. 혈청에서 진단기준은 $7.3 \times 10^{6}$ copies $/ \mathrm{mL}$ 이상이고 소변에서는 $2.2 \times 10^{8} \mathrm{copies} / \mathrm{mL}$ 이상, 정액에서는 $2.9 \times 10^{7}$ copies $/ \mathrm{mL}$ 이상, 모유에서는 $2.0 \times 10^{6} \mathrm{copies} / \mathrm{mL}$ 이상으로 진 단한다. 혈청학적 진단법에는 헤마글루티닌 방해 검사 (Hemagglutinin Inhibition Test), 플라크 감소 중화 시험(Plaque Reduction Neutralization Test), 보체 결합 시험(complement-fixation test), 효소면역측정법(enzyme linked immunoassay) 등이 있는데 항지카바이러스 $\mathrm{IgM}$ 과 $\mathrm{IgG}$ 항체가 3-6일 후 4배 이상 증가할 때 진단할 수 있다[31]. 혈청학적 진단법은 일차 감 염의 경우에는 드물지만, 다른 Flavivirus 감염 후 이차감염이 있었던 경우, 황열 백신을 맞은 이후에는 상호 항원 교차 반 응이 있어 해석에 주의를 요한다[4,11].

임산부가 지카바이러스 유행 지역을 다녀왔을 경우에는 
지카바이러스 검사를 시행하여 양성인 경우 주기적인 태아 초음파를 시행한다. 음성일 경우에는 태아 초음파를 시행하 여 지카바이러스에서 나타날 수 있는 다양한 태아의 신경학 적 이상 소견이 발견되었을 때 다시 지카바이러스 검사를 시 행하고, 태아 초음파상 기형이 없을 경우에는 일반적인 산전 관리만 시행한다. 지카바이러스 유행 지역에 거주는 임산부 는 지카바이러스 감염 증상이 있을 경우 지카바이러스 검사 를 시행하여 양성이면 주기적인 태아 초음파를 시행하고, 음 성이면 태아 초음파를 시행하여 기형이 발견되면 임산부에 게 다시 지카바이러스 검사를 시행하고, 기형이 없으면 일반 적인 산전 관리를 하면 된다. 지카바이러스 유행 지역에 사 는 임산부는 증상이 없어도 지카바이러스 검사를 시행하여 양성이면 주기적인 초음파 검사를 시행하며, 음성인 경우 임 신 18-20주에 태아 초음파와 임신 2기에 지카바이러스 검사 를 시행하여 태아 기형이 있거나 지카바이러스 검사가 양성 인 경우에는 주기적인 태아 초음파를 시행하고, 태아 기형도 없고 지카바이러스 검사가 음성인 경우에는 일반적인 산전 관리를 하고, 태아 초음파를 하기도 하는데, 여기서 태아 기 형이 발견되는 경우 지카바이러스 검사를 시행한다[34].

\section{치료 및 예방}

현재까지 치료약은 없다. 아스피린이나 항소염 진통제는 출혈 위험이 있으므로 피하는 것이 좋다. 백신이 없기 때문 에 예방을 위해서는 모기에 물리지 않도록 해야 한다. 모기 를 피하는 방법으로 모기 기피제, 모기장, 긴 소매 밝은 색 옷 착용 등이 있다. 추천되는 모기 기피제 성분으로는 DEET (N,N-diethyl-meta-toluamide), picaridin (KBR 3023), Bayrepel, icaridin, IR3535, oil of lemon eucalyptus, para-methranediol가 있다[33].

2 개월내 지카바이러스 유행 지역을 다녀온 남성 여행자는 배우자가 임신 중인 경우 임신 기간 동안 금욕 또는 콘돔을 사용하고, 배우자가 임신이 아닌 경우는 최소 2 개월 동안 금 욕 또는 콘돔을 사용한다. 남성 확진 환자는 회복 후 최소 6 개월간 금욕 또는 콘돔을 사용한다. 여성은 귀국 후 최소 2 개월간 임신을 자제하며, 임산부는 가능한 여행을 자제해 야 한다[33,34].

모기 구제를 위해 모기가 알을 낳을 수 있는 물웅덩이, 폐 타이어 등을 제거해야 한다. 유충을 박멸하기 위하여 유충살 균제를 사용할 수 있다. 영국 Oxitec은 유전자 조작 수컷 $A e$. aegypti 모기(OX513A)를 살포하여 교미 후 알을 낳으면 유충 때 죽으므로 유충수를 줄일 수 있는 방법을 개발하였는데, 브라질에서 시행된 연구에서 모기 개체수를 $90 \%$ 감소시키 고, 뎅기열 환자도 한해 132 명에서 4 명으로 줄었다고 발표하 였다[35]. 다른 방법으로 UN국제원자력 기구에서 개발한 수 컷 모기에 방사선을 쪼여 불임 상태를 만들어 방사시키면 알 이 부화하지 못함으로 모기 개체수를 줄이는 Sterile Insect Technology가 있다[36]. 이 방법은 이미 아프리카에서 체체파 리를 억제하기 위해 사용되었다[37]. 생물학적 조절 방법으 로는 세균인 Wolbachia를 이용하는 방법인데 Wolbachia 세균 에 감염된 모기의 경우 암컷 모기의 알이 부화되지 않는다. 이 세균은 사람에게 영향을 미치지 않으며 현재 뎅기열을 줄 이기 위해 이미 사용되고 있고WHO는 대규모 실험에 들어갈 계획이고 중국도 이의 사용을 검토하고 있다[38].

\section{결 론}

아프리카에서 발견되어 이제는 전 세계 여러 나라에서 발 생하고 있는 뎅기바이러스나 치쿤구니야바이러스처럼 지카 바이러스의 확산이 우려되는 상황이다. 특히 지카바이러스 는 감염된 일부 임산부의 태아에서 소두증과 다양한 신경학 적 이상을 유발하고, GBS도 유발한다. 또한 성관계를 통한 남성에서 여성으로의 전파가 확인되었고 최근에는 여성에서 남성으로 전파된 사례도 알려지고 있다[39]. 뎅기바이러스, 치쿤구니야바이러스와 유사한 것 같으면서도 독특한 임상적 특성을 갖는 이 질병이 여름철에 접어든 북반구의 많은 국가 들에서 확산이 우려되는 상황이다. 연구와 신약 개발 역량을 집중하여 빠른 시간 내에 효과적인 백신과 치료제를 개발하 고 질병의 확산을 억제하기 위한 효과적인 보건 정책과 국제 공조가 필요하다.

중심 단어: 지카바이러스; 플라비바이러스; 소두증; 숲 모기

\section{REFERENCES}

1. International Committee on Taxonomy of Viruses. Virus taxonomy: 2014 release [Internet]. London (UK): International Committee on Taxonomy of Viruses, c2014 [cited $2015 \mathrm{Feb}$ 2]. Available from: http://www.ictvonline.org/virustaxonomy.asp. 
2. Zika virus. Emerg Infect Dis 2014;20:1090.

3. Korea Centers for Disease Control and Prevention. Situation report: Zika virus [Internet]. Cheongju (KR): Korea Centers for Disease Control and Prevention, c2016 [cited 2016 July 12]. Available from: http://www.cdc.go.kr/CDC/contents/ CdcKrContentView.jsp?cid=66993\&menuIds=HOME001MNU2374-MNU2365-MNU2367.

4. Musso D, Gubler DJ. Zika virus. Clin Microbiol Rev 2016;29:487-524.

5. Dick GW, Kitchen SF, Haddow AJ. Zika virus. I. Isolations and serological specificity. Trans R Soc Trop Med Hyg 1952;46:509-520.

6. Smithburn KC. Neutralizing antibodies against certain recently isolated viruses in the sera of human beings residing in East Africa. J Immunol 1952;69:223-234.

7. Olson JG, Ksiazek TG, Suhandiman, Triwibowo. Zika virus, a cause of fever in Central Java, Indonesia. Trans R Soc Trop Med Hyg 1981;75:389-393.

8. Lanciotti RS, Kosoy OL, Laven JJ, Velez JO, Lambert AJ, Johnson AJ, Stanfield SM, Duffy MR. Genetic and serologic properties of Zika virus associated with an epidemic, Yap State, Micronesia, 2007. Emerg Infect Dis 2008;14:1232-1239.

9. Duffy MR, Chen TH, Hancock WT, et al. Zika virus outbreak on Yap Island, Federated States of Micronesia. N Engl J Med 2009;360:2536-2543.

10. Cao-Lormea VM, Roche C, Teissier A, et al. Zika virus, French Polynesia, South Pacific, 2013. Emerg Infect Dis 2013;20:1085-1086.

11. Zanluca C, Dos Santos CN. Zika virus - an overview. Microbes Infect 2016;18:295-301.

12. Zanluca C, Melo VC, Mosimann AL, Santos GI, Santos CN, Luz K. First report of autochthonous transmission of Zika virus in Brazil. Mem Inst Oswaldo Cruz 2015;110:569-572.

13. Campos GS, Bandeira AC, Sardi SI. Zika virus outbreak, Bahia, Brazil. Emerg Infect Dis 2015;21:1885-1886.

14. World Health Organization. Cumulative Zika suspected and confirmed cases reported by countries and territories in the Americas, 2015-2016 [Internet]. Geneva (SUI): World Health Organization; c2016 [cited 2016 July 21]. Available from: http://ais.paho.org/phip/viz/ed_zika_cases.asp.

15. Jang HC, Park WB, Kim UJ, et al. First imported case of Zika virus infection into Korea. J Korean Med Sci 2016;31:1173-1177.

16. Lanciotti RS, Lambert AJ, Holodniy M, Saavedra S, Singor Ldel C. Phylogeny of Zika virus in western hemisphere, 2015. Emerg Infect Dis 2016;22:933-935.

17. Haddow AD, Schuh AJ, Yasuda CY, et al. Genetic characterization of Zika virus strains: geographic expansion of the Asian lineage. PLoS Negl Trop Dis 2012;6:e1477.

18. Kostyuchenko VA, Lim EX, Zhang S, et al. Structure of the thermally stable Zika virus. Nature 2016;533:425-428.

19. Petersen E, Wilson ME, Touch S, et al. Rapid spread of Zika virus in the Americas--implications for public health preparedness for mass gatherings at the 2016 Brazil Olympic Games. Int J Infect Dis 2016;44:11-15.

20. Atkinson B, Hearn P, Afrough B, et al. Detection of Zika virus in semen. Emer Infect Dis 2016;22:940.

21. Foy BD, Kobylinski KC, Chilson Foy JL, et al. Probable non-vector-borne transmission of Zika virus, Colorado, USA. Emerg Infect Dis 2011;17:880-882.

22. Deckar DT, Chung WM, Brooks JT, et al. Male-to-male sexual transmission of Zika virus - Texas, January 2016. MMWR Morb Mortal Wkly Rep 2016;65:372-374.

23. Reuters. Canada confirms its first sexually transmitted Zika case. New York (USA): FOX News, c2016 [cited 2016 May 25]. Available from: http://www.foxnews.com/health/2016/ 04/26/canada-confirms-its-first-sexually-transmitted-zikacase.html.

24. Anaya JM, Ramirez-Santana C, Salgado-Castaneda I, Chang C, Ansari A, Gershwin ME. Zika virus and neurologic autoimmunity: the putative role of gangliosides. BMC Med 2016;14:49.

25. Pan American Health Organization; World Health Organiza tion. 17 February 2016: Epidemiological update: Zika virus infection [Internet]. Washington (USA): Pan American Hea1th Organization, c2016 [cited 2016 May 30]. Available from: http://www.paho.org/hq/index.php?option=com_docman\& task $=$ doc_view\& Itemid=270\&gid=33296\&lang=en.

26. Xinhua. Brazilian study links Zika virus to more neurological disorders. Shanghai (CHN): Shanghai Daily, c2016 [cited 2016 May 25]. Available from: http://www.shanghaidaily. com/world/Brazilian-study-links-zika-virus-to-more-neurological-disorders/shdaily.shtml.

27. Mlakar J, Korva M, Tul N, et al. Zika virus associated with microcephaly. N Engl J Med 2016;374:951-958.

28. Brasil P, Pereira JP Jr, Raja Gabaglia C, et al. Zika virus infection in pregnant women in Rio de Janeiro: preliminary report. N Engl J Med 2016 Mar 4 [Epub]. http://www.dx.doi. org/10.1056/NEJMoa1602412.

29. Garcez PP, Loiola EC, Madeiro da Costa R, et al. Zika virus impairs growth in human neurospheres. Advanced understandings for Zika virus brain organoids. Science 2016;352:816-818.

30. Rasmussen SA, Jamieson DJ, Honein MA, Petersen LR. Zika virus and birth defects--reviewing the evidence for causality. N Engl J Med 2016;374:1981-1987.

31. Oehler E, Watrin L, Larre P, et al. Zika virus infection complicated by Guillain-Barre syndrome--case report, French Polynesia, December 2013. Euro Surveill 2014;19. pii: 20720.

32. Centers for Disease Control and Prevention. Revised diag- 
nostic testing for Zika, chikungunya, and dengue viruses in US Public Health Laboratories [Internet]. Atlanta (USA): Centers for Disease Control and Prevention, c2016 [cited 2016 May 25]. Available from: http://www.cdc.gov/zi$\mathrm{ka} / \mathrm{pdfs} /$ denvchikvzikv-testing-algorithm.pdf.

33. Korea Centers for Disease Control and Prevention. Guidelines for Zika virus infection [Internet]. Cheongju (KR): Korea Centers for Disease Control and Prevention, c2016 [cited 20 16 Feb 4]. Available from: http://www.cdc.go.kr/CDC/info/ CdcKrIntro1028.jsp?menuIds=HOME001-MNU1132-MN U2365-MNU2368.

34. Oduyebo T, Petersen EE, Rasmussen SA, et al. Update: interim guidelines for health care providers caring for pregnant women and women of reproductive age with possible Zika virus exposure - United States, 2016. MMWR Morb Mortal Wkly Rep 2016;65:122-127.

35. Carvalho DO, McKemey AR, Garziera L, et al. Suppression of a field population of Aedes aegypti in Brazil by sustained release of transgenic male mosquitoes. PLoS Negl Trop Dis 2015;9:e0003864.

36. Leftwich PT, Bolton M, Chapman T. Evolutionary biology and genetic techniques for insect control. Evol Appl 2015;9: 212-230.

37. Leal Mubarqui R, Perez RC, Kladt RA, et al. The smart aerial release machine, a universal system for applying the sterile insect technique. PLoS One 2014;9:e103077.

38. Molloy JC, Sommer U, Viant MR, Sinkins SP. Wolbachia modulates lipid metabolism in Aedes albopictus mosquito cells. Appl Environ Microbiol 2016;82:3109-3120.

39. Davidson A, Slavinski S, Komoto K, Rakeman J, Weiss D. Suspected female-to-male sexual transmission of Zika virus - New York City, 2016. MMWR Morb Mortal Wkly Rep 2016;65:716-717. 